\title{
KESENJANGAN SOSIAL TERHADAP PENDIDIKAN SEBAGAI PENGARUH ERA GLOBALISASI
}

\author{
Anwar Hidayat \\ Universitas Buana Perjuangan Karawang
}

Email: anwar.hidayat@ubpkarawang.ac.id

\begin{abstract}
Abstrak
Era globalisasi dan modernisasi ini, pembaharuan di bidang pendidikan dilakukan terus-menerus agar mampu menghadapi berbagai tantangan sesuai perkembangan zaman. Tantangan yang dihadapi sistem pendidikan meliputi persoalan-persoalan pemerataan, mutu, relevansi dan efisiensi pendidikan. Salah satu upaya bersama yang diyakini mampu memacu dan membangun keunggulan kualitas pendidikan adalah pemerataan pendidikan secara sarana dan prasarana yang mendukung proses pendidikan tersebut dimanapun daerah atau lokasi seluruh Indonesia. Peran pemerintah dan masyarakat diperlukan untuk memberikan dorongan kepada antar warga negara bahwa pendidikan mempunyai arti penting dan tujuan yang mulia khususnya menjadikan bangsa Indonesia mempunyai kualitas yang baik di mata dunia. Kesenjangan sosial berkaitan dengan pendidikan harus mampu diminimalisir bahkan diselesaikan agar tidak menjadi konflik yang berkepanjangan di masyarakat. Upaya dalam menghadapi kesenjangan sosial terhadap pendidikan dalam era globalisasi yang dikaitkan pada telaah ilmu pengetahuan berupa telaah ontologis, epistemologis dan aksiologis. Ketiga metode tersebut pada dasarnya sama-sama membahas tentang hakikat, hanya saja berangkat dari hal yang berbeda dan mempunyai tujuan yang berbeda pula.
\end{abstract}

Kata Kunci: Kesenjangan Sosial, Pendidikan,

Era Globalisasi

\begin{abstract}
This era of globalization and modernization, renewal in the field of education is carried out continuously in order to be able to face various challenges according to the times. The challenges facing the education system include issues of equity, quality, relevance and efficiency of education. One joint effort that is believed to be able to spur and build excellence in the quality of education is equal distribution of education through facilities and infrastructure that support the educational process wherever the region or location throughout Indonesia. The role of government and society is needed to give encouragement to citizens that education has an important meaning and noble goals, especially making the Indonesian people have good quality in the eyes of the world. Social inequalities related to education must be minimized and even resolved so as not to become a prolonged conflict in the community. Efforts to deal with social inequalities in education in the era of globalization are linked to the study of science in the form of ontological, epistemological and axiological studies. The three methods are basically both discussing the nature, only departing from different things and having different goals.
\end{abstract}

Keywords: Social Inequality, Education, Globalization Era 


\section{PENDAHULUAN}

\begin{abstract}
Pendidikan merupakan suatu usaha yang dilakukan oleh manusia dalam memperoleh pengetahuan serta dapat mengembangkan potensi dirinya $\mathrm{m}$ elalui
\end{abstract} proses pembelajaran dan/atau dengan metode lain dimana masyarakat mengakui proses tersebut. Pendidikan sebagai langkah untuk mengetahui dan memahami setiap perilaku dan kegiatan yang dilakukan manusia yang berkaitan dengan kehidupannya sehari-hari. Di Indonesia telah menyatakan pentingnya pendidikan terhadap seluruh warga negara Indonesia, hal ini sebagiamana telah diamanatkan di dalam Undang-Undang Dasar Republik Indonesia Tahun 1945 yakni setiap warga negara berhak mendapatkan pendidikan dan Pemerintah mengusahakan dan menyelenggarakan satu sistem pendidikan nasional yang meningkatkan keimanan, dan ketaqwaan serta akhlak mulia dalam rangka mencerdaskan kehidupan bangsa yang diatur dengan undang-undang. ${ }^{1}$ Oleh karena itu, seluruh komponen bangsa wajib mencerdaskan kehidupan kehidupan bangsa yang merupakan salah satu tujuan negara Indonesia.

Institusi pendidikan formal atau sekolah merupakan lembaga wawasan dan ilmu pengetahuan, serta penunjang masa

1 Pasal 31 ayat (1) Undang-Undang Dasar Negara Republik Indonesia Tahun 1945 depan yang cerah. Sekolah diasumsikan sebagai tempat yang lebih efektif untuk mengembangkan ilmu pengetahuan. Pendidikan formal (sekolah) bertujuan menyiapkan para peserta didik dalam memasuki masyarakat, pendidikan sekolah mempunyai mitos bahwa semua orang memiliki kesempatan yang sama dalam pendidikan seakan sekolah membuka kesempatan yang sama bagi semua lapisan. ${ }^{2}$

Di era globalisasi dan modernisasi ini, pembaharuan di bidang pendidikan dilakukan terus-menerus agar mampu menghadapi berbagai tantangan sesuai perkembangan zaman. Tantangan yang dihadapi sistem pendidikan meliputi persoalan-persoalan pemerataan, mutu, relevansi dan efisiensi pendidikan. Salah satu upaya bersama yang diyakini mampu memacu dan membangun keunggulan kualitas pendidikan adalah pemerataan pendidikan secara sarana dan prasarana yang mendukung proses pendidikan tersebut dimanapun daerah atau lokasi seluruh Indonesia.

Pengaruh globalisasi dalam perkembangan pendidikan yang terjadi di Indonesia dengan munculnya penyelenggaraan Sekolah Bertaraf Internasional (SBI) dengan beberapa faktor yakni tuntutan daya saing dalam teknologi

2 J.I.G.M Drost S.J, Sekolah Mengajar atau Mendidik, Penerbit Kanisius, Yogyakarta, 1998, hlm. 68 
manajemen dan sumber daya manusia sebagai konsekuensi di era globalisasi. Pemerintah dan/atau pemerintah daerah menyelenggarakan sekurang-kurangnya satu satuan pendidikan pada semua jenjang pendidikan utuk dikembangkan mejadi satuan pendidikan bertaraf internasional. ${ }^{3}$ Filosofi eksistensialisme berkeyakinan bahwa pendidikan harus menyuburkan dan mengembangkan eksistensi peserta didik se-optimal mungkin melalui fasilitas yang dilaksanakan melalui proses pendidikan yang bermartabat serta mengembangkan bakat, minat dan kemampuan peserta didik.

Selain dampak yang dihasilkan dari adanya globalisasi mengenai standarisasi institusi tersebut di atas, kesenjangan sosial dalam dunia pendidikan tampak dari aspek lain yakni keseriusan meningkatkan kualitas pendidikan nasional cukup menjanjikan dengan adanya anggaran khusus untuk pendidikan sebesar 20\% dari APBN serta banyak program pendidikan untuk meringankan biaya pendidikan bagi masyarakat yang kurang mampu secara ekonomi melalui dana Bantuan Operasional Sekolah (BOS), akan tetapi pada kenyataan tingginya biaya pendidikan yang harus menjadi beban masyarakat yang kurang mampu agar anak dan keluarganya dapat menjalankan proses pendidikan sampai

\footnotetext{
${ }^{3}$ Pasal 50 ayat (3) Undang-Undang Nomor 20 Tahun 2003 Tentang Sistem Pendidikan Nasional
}

jenjang yang tinggi. Adanya biaya yang mahal, bagi masyarakat dengan ekonomi yang baik tidaklah menjadi masalah. Dari hal itulah yang menjadi permasalahan yang terjadi sebagai kesenjangan sosial yang ada di dalam masyarakat Indonesia. Program pendidikan yang diluncurkan oleh pemerintah nampaknya tidak serta merta terdistribusikan secara maksimal sebagaimana banyak harapan masyarakat untuk memperoleh pendidikan maksimal.

Realitas yang terjadi selama ini di Indonesia berkaitan dengan pendidikan, masih banyaknya kesenjangan sosial yang terjadi dalam masyarakat untuk memperoleh pendidikan karena faktor ekonomi dan budaya. Bagi daerah-daerah yang terpencil atau lokasi yang sulit untuk diakses maka proses pendidikan tidak berlangsung secara optimal. Perhatian dari pemerintah mengenai pendidikan tidak serta merta dipenuhi layaknya daerah-daerah yang mudah diakses oleh pemerintah. Hal ini menjadi ironis kehidupan yang terjadi di Indonesia, di satu sisi pendidikan merupakan hak yang oleh Undang-Undang Dasar Republik Indonesia Tahun 1945 diakui, namun dalam kenyataan pendidikan itu sendiri masih belum bisa dinikmati masyarakat secara utuh atau maksimal. 


\section{PERMASALAHAN}

Berdasarkan hal-hal yang telah diungkapkan dalam latar belakang, maka dibuat rumusan masalah sebagai berikut:

1. Apa yang menjadi faktor-faktor penyebab kesenjangan sosial terhadap pendidikan?

2. Bagaimana analisis landasan penelaahan ilmu pengetahuan (ontologi,epistemologi dan aksiologi) mengenai kesenjangan sosial terhadap pendidikan sebagai pengaruh era globalisasi?

\section{METODE PENELITIAN}

Penelitian ini menggunakan metode pendekatan yuridis sosiologis yaitu untuk mengevaluasi keterkaitan aspek-aspek empiris. Metode penelitian yang dilakukan dalam program ini diawali dengan pengumpulan data awal metode deskriptif. Informasi awal yang sudah didapatkan selanjutnya akan dicari akar permasalahannya lalu dijabarkan dalam bentuk teori dengan mendapatkan dukungan bahan dari informasi kepustakaan terkait yang bersifat relevan. Program penelitian ini akan melakukan penelitian langsung terhadap lembaga atau obyek penelitiannya (penelitian lapangan).

Sumber data merupakan asal dari mana data penelitian dapat diperoleh. Sumber data yang dipergunakan dalam penelitian ini meliputi: a) Data Primer, merupakan data pokok yang diperlukan dalam penelitian yang berasal dari responden dan informan dan merupakan sumber data utama yang diperoleh peneliti dari responden dan Informan

b) Data Sekunder, merupakan data yang menunjang data primer dan merupakan pelengkap bagi data primer. Data sekunder ini merupakan data dari penelitian kepustakaan, yang terdiri dari 3 (tiga) bahan hukum yakni :

- Bahan hukum primer adalah bahan hukum yang sifatnya mengikat berupa peraturan perundangundangan yang berlaku dan ada kaitannya dengan permasalahan yang dibahas, antara lain Undang-Undang Dasar Republik Indonesia Tahun 1945 dan Undang-Undang Nomor 20 Tahun 2003 Tentang Sistem Pendidikan Nasional.

- Bahan hukum sekunder adalah bahan hukum yang sifatnya menjelaskan bahan hukum primer, dimana bahan hukum sekunder berupa literaur, hasil karya penelitian (jurnal, karya ilmiah).

- Bahan hukum tersier adalah bahan hukum sebagai pelengkap dari kedua bahan hukum sebelumnya, yang berupa kamus hukum dan kamus bahasa Indonesia. 


\section{PEMBAHASAN}

\section{A. Faktor-Faktor Penyebab Kesenjangan}

\section{Sosial Terhadap Pendidikan}

Pendidikan yang telah diamanatkan oleh Undang-Undang Dasar Republik Indonesia Tahun 1945 menjadi hak dasar bagi seluruh warga negara Indonesia untuk mendapatkan pendidikan secara merata dan maksimal, sebagai hak konstitusional maka negara yang dalam hal ini pemerintah yang menjadi tanggung jawab harus dipenuhi hak mendapatkan pendidikan tersebut dengan baik. Permasalahan yang selama ini timbul diantaranya kurangnya perhatian pemerintah dalam menyediakan sarana dan prasarana pendidikan yang didistribusikan hingga wilayah-wilayah terpencil, terluar dan pelosok daerah yang masih dalam wilayah Negara Kesatuan Republik Indonesia.

Program dari pemerintah yang telah memberikan anggaran untuk dana pendidikan sebesar $20 \%$ dari APBN dan dengan berbagai program yang memberikan kemudahan bagi warga negara untuk mendapatkan fasilitas pendidikan yang memadai belum sesuai harapan. Perlunya keseriusan pemerintah sebagai stakeholder dan pembuat kebijakan untuk dapat meningkatkan kualitas pendidikan sebagai langkah menciptakan sumber daya manusia yang memadai, cerdas dan mampu berdaya saing dengan bangsa-bangsa asing untuk menghadapi tantangan hidup di masa yang akan datang. Pendidikan menjadi hal paling sering untuk diamati dan disoroti, karena melalui pendidikan yang dijalankan akan berdampak pada generasi-generasi dalam memajukan bangsanya. Melalui pendidikan mampu menciptakan generasi muda yang mempunyai kemampuan serta keterampilan dalam ilmu pengetahuan yang menunjang pembangunan di segala bidang. Adanya kemajuan ilmu pengetahuan dan teknologi yang disertai dengan semakin pesatnya arus globalisasi sehingga membawa dampak tersendiri bagi dunia pendidikan dikarenakan pendidikan itu sendiri merupakan bagian dari kebudayaan yang tidak bisa dilepaskan dari pengaruh globalisasi.

Secara geografis bangsa Indonesia tersusun dari beberapa pulau-pulau, sehingga masing-masing dari wilayah pulau tersebut dipisahkan oleh perairan dan hutan-hutan yang ada. Sebagai konsekuensi atas negara kepulauan, pemerintah mampu memberikan pemerataan pembangunan secara ekonomi kepada warga negaranya, begitupun dalam bidang pendidikannya. Namun sampai saat ini memang belum terwujud pemerataan pembangunan tersebut, khususnya mengenai pendidikan seperti fasilitas sarana dan prasarana, tenaga pengajar, minat/motivasi warga negara akan pentingnya pendidikan. Jika dibandingkan dengan daerah-daerah yang aksesibilitasnya 
mudah dijangka, maka pembangunan yang berkembang dengan baik. Hal itulah yang menjadi kesenjangan sosial dari masyarakat yang harus diterima, kualitas pendidikan yang berbeda menjadi ironis sebagai permasalahan yang serius untuk diselesaikan.

Oleh karena itu, perlu dikemukakan mengenai faktor-faktor yang menyebabkan terjadinya kesenjangan sosial dalam bidang pendidikan. Beberapa faktor tersebut secara lengkap dijelaskan sebagai berikut :

1) Rendahnya kualitas sarana sekolah;

Sarana sebagai salah satu penunjang kebutuhan keberlangsungan pendidikan menjadi bagian penting, seperti gedung sekolah, media belajar, fasilitas perpustakaan, laboratorium, dan lain-lain. Sarana pembelajaran menjadi terpuruk atau rendah terutama bagi penduduk yang di daerah terpencil/pelosok. Jika dibandingkan dengan dengan kualitas fisik yang berada di kota-kota besar, mereka memiliki fasilitasfasilitas yang memadai, mulai dengan pembangunan gedung, media belajar yang lengkap, dan sebagainya.

2) Rendahnya kualitas guru;

Kualitas pendidikan dapat ditentukan dengan sumber daya manusia (pengajar/guru/dosen) yang memiliki kompetensi dalam menjalankan pendidikan kepada peserta didik, tenaga pengajar (guru) menjadi harapan bagi peserta didik untuk dapat mentransfer ilmu pengetahuan secara baik. Guru yang mempunyai pengalaman dan kemampuan yang mumpuni maka akan dapat menciptakan generasi muda menjadi cerdas dan berkualitas baik. Keadaan ini menjadi memprihatinkan ketika dibandingkan dengan daerah terpencil, dimana ketersediaan guru atau tenaga pengajar masih jauh dari kebutuhan yang seharusnya. 3) Faktor infrastruktur;

Infrastruktur merupakan salah satu faktor yang mempengaruhi keberhasilan penyelenggaraan pendidikan. Aspek infrastruktur yang berkaitan dengan tercapainya pendidikan tidak hanya jumlah dan kondisi fisik sekolah, akan tetapi mengenai aksesibilitas menuju lokasi sekolah yang memberikan kemudahan bagi peserta didik. Hal ini menjadi bertolak belakang dengan daerah yang berada di pelosok, sehingga akses menuju sekolah sulit untuk ditempuh dan cenderung menghambat kelancaran proses belajar dari peserta didik.

4) Jumlah dan kualitas buku (referensi);

Buku atau referensi merupakan unsur yang mampu membantu peserta didik dan tenaga pengajar untuk memudahkan proses belajar mengajar. Ketersediaan dan kualitas buku menjadi penting untuk keberlangsungan pendidikan, sebagaimana disebutkan bahwa setiap satuan pendidikan wajib memiliki sarana yang meliputi perabot, peralatan pendidikan, media 
pendidikan, buku dan sumber belajar lainnya, bahan habis pakai, serta perlengkapan lain yang diperlukan untuk menunjang proses pembelajaran yang teratur dan berkelanjutan. ${ }^{4}$

5) Mahalnya biaya pendidikan;

Biaya pendidikan menjadi acuan dalam mendapatkan pendidikan dengan kualitas masing-masing, seperti biaya sekolah yang mahal akan mendapatkan banyak fasilitas yang sangat memadai sebagai penunjang, sebaliknya biaya yang murah hanya terdapat fasilitas penunjang seadanya. Adanya anggaran yang diberikan oleh pemerintah diharapkan dapat memberikan keringanan biaya khususnya bagi masyarakat ekonomi menengah ke bawah. Namun realitasnya, selama ini belum dapat dimaksimalkan anggaran tersebut dan belum ada pemerataannya.

6) Standarisasi Pendidikan yakni Sekolah Berstandar Nasional (SBN) dan Rintisan Sekolah Bertaraf Internasional (RSBI);

Faktor ini menjadi sorotan yang berdampak pada kesenjangan sosial yang terjadi di masyarakat. Adanya pengelompokan sekolah tersebut berdampak pada mutu dan pelayanan yang diberikan, pemerintah sebagai pemangku kebijakan harus berdasar pada landasan konstitusional bahwa pendidikan adalah hak warga negara, artinya pemenuhan hak pendidikan tersebut harusnya sama tidak ada perbedaan satu dengan lainnya. Kebijakan pemerintah mengenai RSBI justru menciptakan kesenjangan yang mencolok mengenai mutu dan pelayanan pendidikan. Pada dasarnya mutu pendidikan yang baik bukan hanya untuk sekelompok orang, melainkan untuk semua anak bangsa.

Berdasar pada faktor-faktor diatas mengenai kesenjangan sosial terhadap pendidikan, maka perlu keseriusan pemerintah dan peran serta masyarakat untuk bersatu dalam meningkatkan mutu pendidikan. Pemerintah mempunyai kewajiban untuk dapat memberikan kebutuhan yang menunjang proses pendidikan dari wilayah perkotaan hingga sampai daerah-daerah yang terpencil atau pelosok. Peran masyarakat diperlukan untuk memberikan dorongan kepada antar warga negara bahwa pendidikan mempunyai arti penting dan tujuan yang mulia khususnya menjadikan bangsa Indonesia mempunyai kualitas yang baik di mata dunia. Kesenjangan sosial berkaitan dengan pendidikan harus mampu diminimalisir bahkan diselesaikan agar tidak menjadi konflik yang berkepanjangan di masyarakat.

\footnotetext{
${ }^{4}$ Pasal 42 ayat (1) Peraturan Pemerintah Nomor 19 Tahun 2005 tentang Standar Nasional Pendidikan
} 
B. Analisis Landasan Penelaahan Ilmu Pengetahuan (Ontologi, Epistemologi Dan Aksiologi) Mengenai Kesenjangan Sosial Terhadap Pendidikan Sebagai Pengaruh Era Globalisasi

Pendidikan merupakan wahana untuk mendapatkan pengetahuan atas suatu hal, lembaga pendidikan merupakan wadah untuk pewarisan dan pelestarian nilai-nilai dan pengetahuan. Persoalan yang timbul dalam dunia pendidikan harus segera dituntaskan agar tidak menjadi masalah yang mengakar artinya tidak mempunyai upaya dan strategi dalam menyelesaikannya khususnya dalam kesenjangan sosial terhadap pendidikan. Dalam pembahasan ini, penulis akan mengemukakan upaya dalam menghadapi kesenjangan sosial terhadap pendidikan dalam era globalisasi yang dikaitkan pada telaah ilmu pengetahuan berupa telaah ontologis, epistemologis dan aksiologis. Ketiga metode tersebut pada dasarnya sama-sama membahas tentang hakikat, hanya saja berangkat dari hal yang berbeda dan mempunyai tujuan yang berbeda pula.

Aspek ontologis adalah berawal dari bahasa Yunani yakni On/Ontos artinya ada dan logos artinya ilmu. Jadi ontologis mempunyai arti ilmu tentang yang ada. Menurut istilah ontologi adalah ilmu yang membahas tentang hakikat yang ada, yang merupakan ultimate reality baik yang berbentuk jasmani/konkret maupun rohani/abstrak ${ }^{5}$, sedangkan Suriasumantri, bahwa ontologi adalah membahas tentang apa yang ingin kita ketahui, seberapa jauh kita ingin tahu, atau suatu pengkajian mengenai teori tentang "ada". Dimana dalam telaah ontologis akan menjawab beberapa pertanyaan-pertanyaan, yakni : a) apakah obyek ilmu yang akan ditelaah; b) bagaimana wujud yang hakiki dari obyek tersebut; dan c) bagaimana hubungan antara obyek tadi dengan daya tangkap manusia (seperti berfikir, merasa, dan mengindera) yang membuahkan pengetahuan. ${ }^{6}$

Dalam kajian ontologis bahwa hakikatnya manusia merupakan subjek pendidikan (tenaga pengajar/guru dan perserta didik), hakikat manusia sebagai makhluk yang spesial dari makhlukmakhluk ciptaan Alloh SWT yang lainnya. Dalam firman Allah yang terdapat pada QS. Al Baqarah ayat 30, menyebutkan :

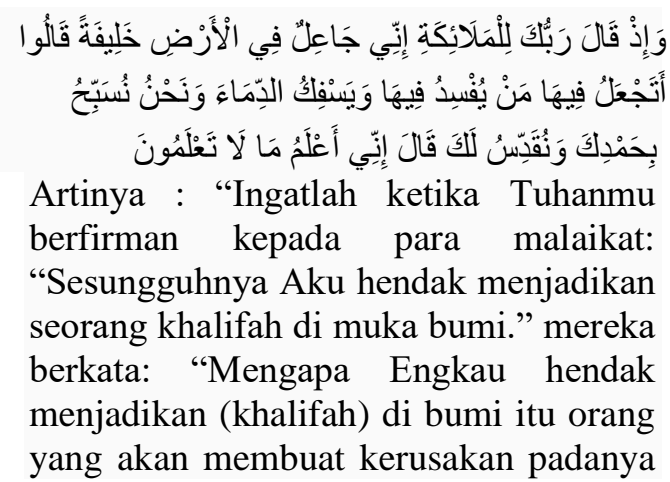

${ }^{5}$ Amsal Bakhtiar, Filsafat Ilmu, Penerbit Raja Grafindo Persada, Jakarta, 2010, hlm. 35

${ }^{6}$ Jujun S Suriasumantri, Filsafat Ilmu Sebuah Pengantar Populer, Pustaka Sinar Harapan Jakarta, 1990, hlm. 50 
dan menumpahkan darah, padahal kami senantiasa bertasbih dengan memuji Engkau dan mensucikan Engkau?" Tuhan berfirman: "Sesungguhnya Aku mengetahui apa yang tidak kamu ketahui."

Berdasarkan pada firman Allah diatas, manusia difokuskan dan ditakdirkan menjadi pemimpin di bumi, serta perlu pengetahuan yang luas untuk mempelajari peran-peran sebagai khalifah di bumi. Peran dan bagaimana manusia bersikap dapat diperoleh dengan melalui pendidikan yang harus dilaksanakan. Karena dengan pendidikan itu tidak lain diperuntukan bagi manusia, agar tidak timbul kerusakan di muka bumi. Oleh karena itu, dengan memahami aspek ontologi mengenai pendidikan tersebut, maka diharapkan bisa menumbuhkan kesadaran para pendidik dan peserta didik untuk menjalankan peran dan fungsinya dalam keberlangsungan pendidikan di tengah-tengah peradaban manusia yang semakin berkembang pesat seperti dalam era globalisasi sekarang ini.

Apek epistemologis adalah berawal dari kata "episteme" artinya pengetahuan, dan "logos" artinya ilmu. Epsitemologi atau teori pengetahuan ialah cabang filsafat yang berurusan dengan hakekat dan lingkungan pengetahuan, pengandaian-pengandaian dan dasar-dasarnya serta pertanggungjawaban atas pernyataan mengenai pengetahuan yang dimiliki. Epistemologi adalah pembahasan mengenai metode yang digunakan untuk mendapatkan pengetahuan. Dalam epistemologis membahas pertanyaan-pertanyaan seperti : a) bagaimana prosedurnya; b) hal-hal apa yang harus diperhatikan agar kita mendapatkan pengetahuan yang benar; c) benar itu apa; dan d) kriterinya apa saja.

Kajian epistemologi dalam bidang pendidikan diperlukan antara lain mengenai pengetahuan apa yang harus diberikan kepada peserta didik dan bagaimana cara memperoleh pengetahuan, beserta bagaimana cara menyampaikan pengetahuan tersebut. Pada sudut epistemologi adalah seharusnya pengetahuan apa yang harus diberikan kepada peserta didik?. Hal ini terkait dengan pengetahuan akan kebutuhan yang diperlukan peserta didik, sebagai contoh perlakuan antara siswa yang memiliki kamampuan intelektualitas tinggi dengan yang standar, hal itu berhubungan dengan fasilitas-fasilitas yang mendukung proses pendidikan tersebut. Bagaimana cara memperoleh pengetahuan dalam dunia pendidikan cara memperoleh pengetahuan yang sesuai dengan kebutuhan peserta didik harusnya sama, dalam keadaan seperti apapun warga negara memperoleh hak yang sama untuk mendapatkan pendidikan sebagaimana diamanatkan dalam UUD Negara Republik Indonesia Tahun 1945. Kompetensi sumber daya manusia (guru/tenaga pengajar) harus memadai agar 
pengetahuan yang disampaikan kepada peserta didik bisa dipahami secara maksimal. Bagaimana cara menyampaikannya?, pertanyaan ini terkait dengan kompetensi guru serta metode atau gaya pengajaran yang mereka terapkan. Sebenarnya jaman sekarang ini model ceramah yang bersifat pasif sudah bukan jamannya lagi, namun ada metode yang dapat diberikan yakni belajar sambil melakukan (learning by doing).

Aspek aksiologis adalah berawal dari bahasa Yunani yaitu axios yang berarti nilai, dan logos berarti ilmu. Pengertian aksiologi menurut Jujun S. Suriasumantri adalah teori nilai yang berkaitan dengan kegunaan dari ilmu pengetahuan yang diperoleh. ${ }^{7}$ Sedangkan Wibisono mengemukakan bahwa aksiologi adalah nilai-nilai sebagai tolak ukur kebenaran etika dan moral sebagai dasar normative penelitian dan penggalian serta penerapan ilmu.

Kajian aksiologi dalam pendidikan ini bahwa ilmu pengetahuan mengandung nilai dan kebenaran terhadap suatu hal. Eksistensi ilmu pengetahuan bukan hanya untuk mendesak pengetahuan melainkan kemanusiaanlah yang menggenggam ilmu pengetahuan untuk kepentingan dirinya dalam rangka penghambaan diri kepada Tuhan Yang Maha Esa. Seperti pendidikan

\footnotetext{
${ }^{7}$ Jujun S. Suriasumantri, Ibid, hlm. 60.
}

agama yakni mengarahkan ilmu pengetahuan pada tujuan hakikinya yaitu memahami realitas alam dan memahami eksistensi Tuhan, agar manusia sadar akan hakikat penciptaan dirinya. Nilai yang penting dalam aspek ini, bertujuan agar manusia mampu mengembalikan ilmu pengetahuan pada jalur semestinya, sehingga ia menjadi berkah dan rahmat bagi manusia juga dengan alam semesta. Nilai dan implikasi aksiologi di dalam pendidikan ialah pendidikan menguji dan menintegrasikan semua nilai-nilai di dalam kehidupan manusia, karena untuk dapat mengatakan sesuatu baik itu bukanlah hal yang mudah, apalagi menilai secara mendalam nilai yang melatarbelakangi keberadaan manusia berada di mua bumi ini.

\section{KESIMPULAN}

Berdasarkan hasil penelitian dan pembahasan yang diangkat, maka dapat disimpulkan bahwa:

1. Faktor-faktor yang menyebabkan terjadinya kesenjangan sosial dalam bidang pendidikan, antara sebagai berikut :

- Rendahnya kualitas sarana sekolah;

- Rendahnya kualitas guru;

- Faktor infrastruktur;

- Jumlah dan kualitas buku (referensi);

- Mahalnya biaya pendidikan;

- Standarisasi Pendidikan yakni Sekolah Berstandar Nasional (SBN) 
dan Rintisan Sekolah Bertaraf Internasional (RSBI);

2. Dalam menghadapi kesenjangan sosial terhadap pendidikan dalam era globalisasi yang dikaitkan pada telaah ilmu pengetahuan berupa telaah ontologis, epistemologis dan aksiologis. Ketiga metode tersebut pada dasarnya sama-sama membahas tentang hakikat, hanya saja berangkat dari hal yang berbeda dan mempunyai tujuan yang berbeda pula. Aspek ontologis yakni mengenai peran dan bagaimana manusia bersikap dapat diperoleh dengan melalui pendidikan yang harus dilaksanakan. Aspek epistemologi yakni dalam bidang pendidikan diperlukan antara lain mengenai pengetahuan apa yang harus diberikan kepada peserta didik dan bagaimana cara memperoleh pengetahuan, beserta bagaimana cara menyampaikan pengetahuan tersebut. Kemudian aspek aksiologi ialah pendidikan menguji dan menintegrasikan semua nilai-nilai di dalam kehidupan manusia.

\section{DAFTAR PUSTAKA}

\section{A. Buku}

Amsal Bakhtiar, Filsafat Ilmu, Penerbit Raja Grafindo Persada, 2010.

J.I.G.M Drost S.J, Sekolah Mengajar atau Mendidik, Penerbit Kanisius, Yogyakarta, 1998.

Jujun S Suriasumantri, Filsafat Ilmu Sebuah Pengantar Populer, Pustaka Sinar Harapan Jakarta, 1990.

S. Smith \& J. Baylis, The Globalization of World Politics, Oxford University Press, London, 2001.

\section{B. Peraturan Perundang-undangan}

Peraturan Pemerintah Nomor 19 Tahun 2005 tentang Standar Nasional Pendidikan.

Undang-Undang Dasar Negara Republik Indonesia Tahun 1945

Undang-Undang Nomor 20 Tahun 2003 Tentang Sistem Pendidikan Nasional. 